Journal Club

Editor's Note: These short, critical reviews of recent papers in the Journal, written exclusively by graduate students or postdoctoral fellows, are intended to summarize the important findings of the paper and provide additional insight and commentary. For more information on the format and purpose of the Journal Club, please see http://www.jneurosci.org/misc/ifa_features.shtml.

\title{
AMPA Receptor Plasticity in the Nucleus Accumbens Mediates Withdrawal-Related Negative-Affective States
}

\author{
(1)Gabor Egervari \\ Departments of Psychiatry and Neuroscience, Icahn School of Medicine at Mount Sinai, New York, New York 10029 \\ Review of Russell et al.
}

Addiction is a chronic, relapsing disorder characterized by craving, compulsive drug use, and loss of control over limiting drug intake (Koob and Volkow, 2010). The emergence of negative-affective states (e.g., dysphoria, anxiety, irritability) with chronic drug use has been hypothesized to play a crucial role in the transition from recreational drug use (characterized by positive reinforcement) to full-blown addiction and compulsive drug seeking (driven mostly by negative reinforcement) This "dark side of addiction" is thought to result from a compensatory decrease in the function of the normal reward neurocircuitry and persistent recruitment of brain stress systems (Koob, 2013). In addicted people, negativeaffective states associated with withdrawal promote drug seeking and relapse; they thus play a central role in the three-stage cycle of addictive behavior (binge/intoxication, withdrawal/negative affect, preoccupation/anticipation) (Koob, 2013). On the circuit level, recreational drug use is mediated by the nucleus accumbens (NAc), whereas compulsive drug-seeking is driven by the dorsal striatum (Everitt and Robbins, 2013). However, the molecular underpinnings of the transition to addiction remain largely elusive. A better understanding of

Received July 22, 2016; revised Aug. 24, 2016; accepted Aug. 26, 2016. The authors declare no competing financial interests.

Correspondence should be addressed to Dr. Gabor Egervari, Departments of Psychiatry and Neuroscience, Icahn School of Medicine at Mount Sinai, One Gustave L. Levy Place, New York, NY 10029. E-mail: gabor.egervari@icahn.mssm.edu.

DOI:10.1523/JNEUROSCI.2329-16.2016

Copyright $(C) 2016$ the authors $\quad 0270-6474 / 16 / 3610505-03 \$ 15.00 / 0$ neural plasticity underlying the emergence of negative-affective states associated with withdrawal and compulsive drug seeking is essential to guide the development of future therapeutic interventions targeting this critical component of the addiction phenomenon (Koob and Mason, 2016).

Plasticity of glutamatergic synapses in the NAc, a key area for integrating motivation, emotion, and reward, has been implicated as a critical component of long-term neuronal maladaptations underlying addictive behavior (Scofield et al., 2016). Chronic morphine exposure, for example, potentiates glutamatergic transmission at thalamostriatal projections by enhancing synaptic insertion of AMPA receptors (Zhu et al., 2016). Further expanding this line of research, a recent publication in The Journal of Neuroscience (Russell et al., 2016) investigated the role of NAc AMPA receptor function in regulating negative-affective states associated with withdrawal in morphinedependent rats. Animals were made dependent by subcutaneous implantation of morphine pellets, and withdrawal was precipitated by subcutaneous delivery of naloxone, a potent $\mu$-opioid receptor antagonist. Withdrawal-induced negative-affective states were assessed by measuring conditioned place aversion. Selective inhibition of AMPA receptors was achieved by injecting antagonist NBQX into the NAc shell, and behaviorally relevant doses were determined based on observed decreases in AMPA-induced locomotion (Russell et al., 2016, their Fig. 1).
Naloxone induced a strong conditioned place aversion in morphine-dependent rats, and this effect was prevented by NBQX pretreatment in the NAc shell (Russell et al., 2016, their Fig. 2 B). The effects were specific to the NAc shell, and none of the treatments showed any effect in placebo-implanted rats. Somatic signs of withdrawal (e.g., irritability to touch, wet dog shakes) were not affected by AMPA receptor blockade (Russell et al., 2016, their Fig. 3). These results indicate that AMPA receptor function in the NAc shell might be selectively involved in the regulation of negative-affective but not somatic signs of morphine withdrawal.

AMPA receptor function plays an important role in both memory formation and forgetting (Migues et al., 2016). To confirm that the observed effects were not due to changes in associative learning or memory impairments, Russell et al. (2016) measured the effects of naloxone and/or NBQX on brain stimulation reward threshold in intracranial self-stimulation (ICSS), an operant paradigm in which rodents self-administer rewarding electrical stimulation via electrodes implanted in the brain (Carlezon and Chartoff, 2007). Decreases and increases in ICSS threshold, defined as the amount of stimulation that is rewarding, indicate heightened or attenuated reward sensitivity, respectively. Naloxone led to significant increases in ICSS thresholds, which were reversed by NBQX pretreatment in the NAc shell (Russell et al., 2016, their Fig. 4D). This is consistent with the hypothesis that NBQX exerts its inhibitory effects by blocking naloxone-induced negative-affective states 

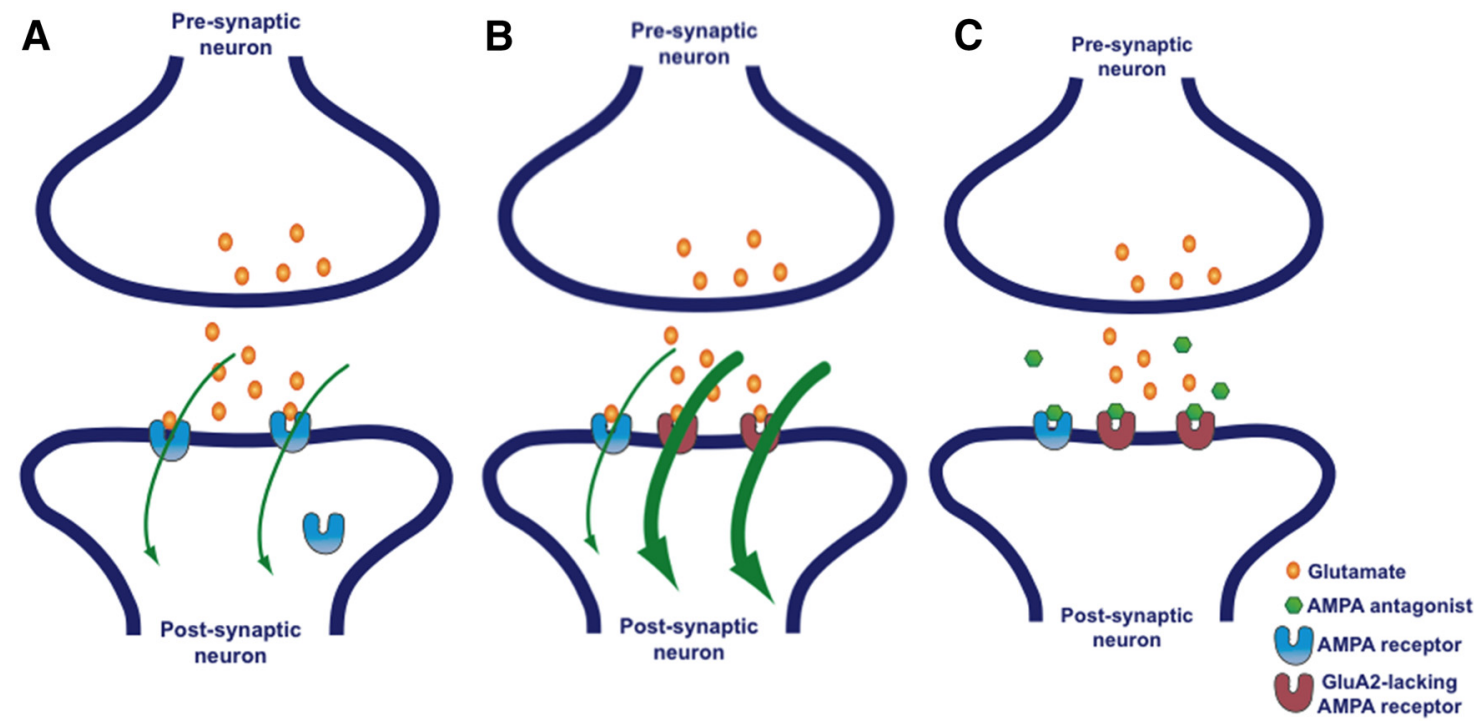

Figure 1. AMPA receptor plasticity in the NAc underlies withdrawal-related negative-affective states. $\boldsymbol{A}$, Glutamatergic synapse in the NAc. $\boldsymbol{B}$, Morphine dependence leads to increased surface expression of AMPA receptors, including GluA2-lacking receptors, resulting in enhanced glutamatergic transmission that underlies the expression of negative-affective states that promote relapse. C, Drug-induced molecular adaptations can be counteracted by using AMPA receptor antagonists, leading to a decrease in receptor function and negative-affective signs.

rather than by disrupting associative learning during conditioned place aversion.

Two mechanisms by which neurotransmission at AMPA-receptor-containing synapses can be regulated are changes in receptor levels and changes in subunit composition. These mechanisms have been strongly implicated in neuronal maladaptations accompanying chronic drug administration. For example, both total (Churchill et al., 1999) and surface (Boudreau and Wolf, 2005; Conrad et al., 2008) expression of the GluA1 AMPA receptor subunit were increased in the NAc after chronic cocaine administration. Withdrawal and reinstatement paradigms also result in increased surface expression of GluA1 in the NAc (Anderson et al., 2008). In addition, somatic signs of morphine withdrawal were decreased by AMPA antagonists or by genetic deletion of GluA1 (Rasmussen et al., 1996; Vekovischeva et al., 2001). Is a similar mechanism also at work in the regulation of affective components of withdrawal?

To assess AMPA receptor subunit composition on the cell surface of NAc neurons, Russell et al. (2016) used BS $^{3}$ to covalently cross-link cell surface proteins while leaving intracellular molecules intact. Morphinedependent rats indeed exhibited significantly higher surface GluA1 levels as well as higher surface/intracellular ratio of GluA1 but not GluA2 subunits (Russell et al., 2016, their Fig. 5). Interestingly, this increase in surface GluA1 was reversed during naloxone-precipitated withdrawal. In addition, naloxone significantly decreased GluA1 protein levels in synaptosomal membranes in morphine-dependent rats, an effect that was specific to GluA1 and the NAc shell (Russell et al., 2016, their Fig. 6).

The increase of GluA1 on the cell surface and in synaptosomal membranes, along with the lack of change of GluA2, potentially suggests an enrichment of GluA2-lacking AMPA receptors in the NAc shell of morphine-dependent rats. Compared with GluA2-containing receptors, GluA2-lacking AMPA receptors are permeable to $\mathrm{Ca}^{2+}$ and exhibit higher single-channel conductance, faster kinetics, increased depolarization, and activation of $\mathrm{Ca}^{2+}$-dependent signaling cascades (Man, 2011). Changes in AMPA receptor subunit composition in glutamatergic synapses might therefore contribute to altered AMPA receptor function in morphine-dependent and naloxone-treated rats, which in turn underlies negative-affective states associated with morphine withdrawal. Indeed, Russell et al. (2016) found that NASPM, a selective inhibitor of GluA2-lacking AMPA receptors, had effects similar to those of NBQX: NASPM significantly attenuated naloxoneinduced increases in brain stimulation thresholds in ICSS, although no such changes were observed in nondependent rats (Russell et al., 2016, their Fig. 8C). This is in line with previous observations that the surface expression of GluA2-lacking AMPA receptors is significantly increased during withdrawal in cocaine self-administering animals (Conrad et al., 2008).

The changes identified by Russell et al. (2016) outline a molecular mechanism for morphine-related postsynaptic potentiation of glutamatergic inputs to the NAc. Increased surface levels of GluA2-lacking
AMPA receptors are consistent with enhanced synaptic transmission, which is necessary for the expression of morphine withdrawal signs (Zhu et al., 2016). The resulting negative-affective states in turn motivate compulsive drug-seeking behavior. This model is consistent with previous literature showing that elevated NAc GluA1 levels result in aversive states (Todtenkopf et al., 2006), and emphasizes the role of glutamatergic inputs to the NAc in promoting drug seeking (LaLumiere and Kalivas, 2008). In line with this hypothesis, chronic morphine exposure potentiated AMPAR transmission at thalamostriatal synapses via insertion of GluA2-lacking receptors (Zhu et al., 2016). This AMPAR potentiation was necessary for morphine withdrawal signs, which were suppressed by optogenetic depotentiation (Zhu et al., 2016).

The observations of Russell et al. (2016) significantly advance our understanding of the molecular underpinnings of negativeaffective states associated with chronic morphine use and withdrawal (Fig. 1). It remains to be seen whether similar mechanisms apply to other addictive substances. In addition, the extent to which the mode of drug delivery influences these adaptations should be investigated. Although subcutaneous implantation of morphine pellets, as performed by Russell et al. (2016), reliably achieves morphine dependence, animals do not actually engage in drug-seeking behavior in this paradigm. Drug self-administration remains the gold standard in the addiction field (Howell and Fantegrossi, 2009) as it is more directly translatable to the human condition and allows investigation 
of multiple aspects of substance use (initiation, maintenance, withdrawal/abstinence, reinstatement/drug-seeking). Other variables, such as the length of withdrawal and the presence or absence of extinction training, are also likely to affect withdrawalrelated negative-affective signs and underlying molecular impairments. Such models are important to fully appreciate the contribution of GluA1-mediated AMPA receptor signaling to morphine-related negativeaffective states, and to evaluate its therapeutic potential for inhibiting drug-seeking behavior by AMPA receptor antagonists.

These caveats notwithstanding, the findings of Russell et al. (2016) add to the growing body of literature suggesting that uncontrollable drug-seeking behavior in long-term substance users is governed by impairments of glutamate homeostasis in the NAc (Kalivas, 2009). The data presented encourage further investigation of other functionally relevant aspects of withdrawalrelated glutamatergic synaptic plasticity (e.g., changes in AMPA/NMDA ratio, spine head morphology, postsynaptic currents) and their contribution to negative-affective states. Considering the crucial role negativeaffective states play in mediating drugseeking behavior, the findings of Russell et al. (2016) raise the possibility of using AMPA receptor antagonists to ameliorate withdrawal-related negative-affective states (Fig. 1) and prevent relapse in human drug users.

\section{References}

Anderson SM, Famous KR, Sadri-Vakili G, Kumaresan V, Schmidt HD, Bass CE, Terwilliger EF, Cha JH, Pierce RC (2008) CaMKII: a biochemical bridge linking accumbens dopamine and glutamate systems in cocaine seek- ing. Nat Neurosci 11:344-353. CrossRef Medline

Boudreau AC, Wolf ME (2005) Behavioral sensitization to cocaine is associated with increased AMPA receptor surface expression in the nucleus accumbens. J Neurosci 25:91449151. CrossRef Medline

Carlezon WA Jr, Chartoff EH (2007) Intracranial self-stimulation (ICSS) in rodents to study the neurobiology of motivation. Nat Protoc 2:2987-2995. CrossRef Medline

Churchill L, Swanson CJ, Urbina M, Kalivas PW (1999) Repeated cocaine alters glutamate receptor subunit levels in the nucleus accumbens and ventral tegmental area of rats that develop behavioral sensitization. J Neurochem 72:2397-2403. CrossRef Medline

Conrad KL, Tseng KY, Uejima JL, Reimers JM, Heng LJ, Shaham Y, Marinelli M, Wolf ME (2008) Formation of accumbens GluR2lacking AMPA receptors mediates incubation of cocaine craving. Nature 454:118-121. CrossRef Medline

Everitt BJ, Robbins TW (2013) From the ventral to the dorsal striatum: devolving views of their roles in drug addiction. Neurosci Biobehav Rev 37:1946-1954. CrossRef Medline

Howell LL, Fantegrossi WE (2009) Intravenous drug self-administration in nonhuman primates. In: Methods of behavior analysis in neuroscience, Ed 2 (Buccafusco JJ, ed). Boca Raton, FL: CRC.

Kalivas PW (2009) The glutamate homeostasis hypothesis of addiction. Nat Rev Neurosci 10: 561-572. CrossRef Medline

Koob GF (2013) Negative reinforcement in drug addiction: the darkness within. Curr Opin Neurobiol 23:559-563. CrossRef Medline

Koob GF, Mason BJ (2016) Existing and future drugs for the treatment of the dark side of addiction. Annu Rev Pharmacol Toxicol 56: 299-322. CrossRef Medline

Koob GF, Volkow ND (2010) Neurocircuitry of addiction. Neuropsychopharmacology 35 : 217-238. CrossRef Medline

LaLumiere RT, Kalivas PW (2008) Glutamate release in the nucleus accumbens core is nec- essary for heroin seeking. J Neurosci 28:31703177. CrossRef Medline

Man HY (2011) GluA2-lacking, calcium-permeable AMPA receptors: inducers of plasticity? Curr Opin Neurobiol 21:291-298. CrossRef Medline

Migues PV, Liu L, Archbold GE, Einarsson EÖ, Wong J, Bonasia K, Ko SH, Wang YT, Hardt O (2016) Blocking synaptic removal of GluA2-containing AMPA receptors prevents the natural forgetting of long-term memories. J Neurosci 36:3481-3494. CrossRef Medline

Rasmussen K, Kendrick WT, Kogan JH, Aghajanian GK (1996) A selective AMPA antagonist, LY293558, suppresses morphine withdrawalinduced activation of locus coeruleus neurons and behavioral signs of morphine withdrawal. Neuropsychopharmacology 15:497-505. CrossRef Medline

Russell SE, Puttick DJ, Sawyer AM, Potter DN, Mague S, Carlezon WA Jr, Chartoff EH (2016) Nucleus accumbens AMPA receptors are necessary for morphine-withdrawal-induced negative-affective states in rats. J Neurosci 36:5748-5762. CrossRef Medline

Scofield MD, Heinsbroek JA, Gipson CD, Kupchik YM, Spencer S, Smith AC, Roberts-Wolfe D, Kalivas PW (2016) The nucleus accumbens: mechanisms of addiction across drug classes reflect the importance of glutamate homeostasis. Pharmacol Rev 68:816-871. CrossRef Medline

Todtenkopf MS, Parsegian A, Naydenov A, Neve RL, Konradi C, Carlezon WA Jr (2006) Brain reward regulated by AMPA receptor subunits in nucleus accumbens shell. J Neurosci 26: 11665-11669. CrossRef Medline

Vekovischeva OY, Zamanillo D, Echenko O, Seppälä T, Uusi-Oukari M, Honkanen A, Seeburg PH, Sprengel R, Korpi ER (2001) Morphineinduced dependence and sensitization are altered in mice deficient in AMPA-type glutamate receptor-A subunits. J Neurosci 21: 4451-4459. Medline

Zhu Y, Wienecke CF, Nachtrab G, Chen X (2016) A thalamic input to the nucleus accumbens mediates opiate dependence. Nature 530: 219-222. CrossRef Medline 